\title{
Projecting the Possible Impacts of the National Economic Empowerment and Development Strategy (NEEDS) on Human Development in Nigeria
}

\author{
Ogundele, O.J.K. PhD \\ Department of Business Administration and Management Technology \\ (Marketing unit) Lagos State University, Ojo, Nigeria \\ Tel: 80-5541-5293 E-mail: oludelekayode@yahoo.com
}

Hassan, A.R. PhD

Department of Business Administration and Management Technology

(Marketing unit) Lagos State University, Ojo, Nigeria

Tel: 80-2324-9232Ｅ-mail: doyinhassan200@yahoo.co.uk

Abdul-Azeez, Ibraheem A. (Corresponding author)

Department of Business Administration and Management Technology

(Management Technology unit) Lagos State University, Ojo, Nigeria

Tel: 70-3655-5582Ｅ-mail: ibforson@yahoo.com

Received: January 16, 2011

Accepted: July 5, 2011

doi:10.5539/ijef.v3n4p162

\begin{abstract}
The study investigated the possible impact of National Economic Empowerment and Development Strategy (NEEDS) on human development in Nigeria. NEEDS is a home-groomed economic and social package focused on fighting poverty and enthroning a people-centered developmental programmes. The paper evaluates each of the major thrusts of NEEDS by highlighting their respective demands for new patterns of human development. Also, collaborative and interactive model of human development is presented. The paper highlights three critical core areas that can enthrone the success of NEEDS for sustainable development. These are evangelistic development of indigenous professionals by providing needed supports in terms of training and development, infrastructural facilities and finance, enforcing the practice of business and social ethics after effective mobilization of the people psychic with the values reorientation component of NEEDS, and applying strict and swift sanctions on violations of social and economic ethics to serve as deterrent for others. It is expected therefore that through effective and efficient implementation, NEEDS will serve as a useful strategy and tool for economic development of Human resources.
\end{abstract}

Keywords: Strategy, Economic empowerment, Human development, Government

\section{Introduction}

Nigeria is the $6^{\text {th }}$ largest oil and gas producer in the world. These minerals and other resources have put Nigeria in a position of a wealthy nation. Yet Nigeria is one of the poorest nations in the world today by all economic indices. This shows apparent contradiction when matched with normal reality. Tremendous resources were wasted year in year out due to lack of people-focused and people oriented developmental programmes, in addition, inappropriate developmental models which were out of tune with the realities of Nigeria environment were applied. The result is that the nation's development programmes have failed to produce any significant and meaningful development.

Nigeria had produced a number of National Development plans, which represented the aims and aspirations of the nation, in charting its path of economic, social and political development. They were usually based on some philosophies or models. The first National Development plan in Nigeria was after independence, 1962 - 1968. There was the Nigerian civil war 1967 - 1970. The second National Development plan was 1970 - 1974. Others are third, National Development Plan 1975 - 1980, Fourth National Development Plan 1981 - 1984, the fifth National Development plan of 1989 and the 3 yearly rolling plans since the vision 1990s which culminated in the vision 2010 for Nigeria (Ogundele and Opeifa, 2004). In the First and Second National Development Plans, the criteria used were: (i) focusing on investment with greatest growth potentials (ii) ensuring the feasibility of various government proposals (iii) Emphasizing economic 
desirability of projects, and (iv) ensuring the achievement of maximum growth rate.

To achieve maximum growth rate, each project was scrutinized in terms of its contributions towards plan goals. The highest order of national priorities was accorded to agriculture, industry, transportation and manpower development. The second order of priority rating were social services and utilities e.g. electricity, communication and water. Other services and projects were regarded as belonging to the third order of priority. Defence and security were in a class by themselves, (Olayide, 1976). Anyanwu et al (1997) observed that the performance of the Nigerian economy during the first two decades after independence (1962 - 1980) was generally more impressive than the pre-independence period, particularly under the first two plans. The average GDP growth rate was 5.1\% during the First National Plan, $8.2 \%$ under the Second and 5.0\% under the third, all of which exceeded the 3.9\% averages in the pre-independence. Yesufu (1996) notes that the growth rate under the Forth development plan was only $1.25 \%$. Some of the factors that militated against the plan implementation included corruption, high level inflation, lack of coherent policies, lack of effective data base, simplistic and optimistic projection, contracts over-valuation and over-invoicing and high level of indiscipline. The Rolling Plans period 1990 - 1999, inherited the problems identified in the 1981 - 1985 plan period. In addition there were problems of ailing government industries, low capacity utilization, and unemployment. The present Democratic Government inherited the set of problems listed above, in May 1999.

Akintoye and Awosisa (2000) argue that while the models that were employed in the plan periods highlighted above which range from Laisez Faire, Keynesian, proto-socialist thoughts, Maxian and Harrod - Dormar Models would hold good in advanced economies where there is high spirit of economic nationalism. They are unstable in our own environment. This is because of lack of institutional and behavioral conditions to convert new capital into productive output. That others include; low rate of savings, in some cases saving do not exist in the right quantity, loans and aids given do not produce the same results as in advance countries due to bribery, corruption and in congenial investment climate. Therefore a positive development - management model has to be evolved, in the path of purposeful development and significant growth, the National Economic Empowerment and Development Strategy (NEEDS) is response to these requirements.

\section{Conceptual Framework}

Development could be regarded as gradual growth from within the individual, an organization and a nation, which results in a better and more desirable state than the present or previously existing states. Fadeyi (2004) notes that in a broader sense development encompasses economic, and other important attributes as well, particularly equality of opportunity political freedom, civil liberties, gender equality, environmental protection, poverty reduction and several other issues. In respect of human development, it is a systematic process of training and growth through which the individuals gain and apply skill, knowledge, insight and attitude to manage work organization effectively (Baech, 1975). Thus development results in growth or change in outlook, activities, skills and other relevant processes which enable people to relate more productive in the environment in which they are located. Torado and Smith (2003), note that development has three core values. These are: (i) Sustenance which is concerned with ability to maintain and improve on present condition in future (ii) Self-esteem, that sense of worth and self-respect and (iii) Freedom from servitude, which is human freedom of being able to choose. They note further that development has three objectives; to increase the availability and widen the distribution of the basic life sustaining goods; to raise levels of living in terms of higher income, provision of jobs, better education greater attention to cultural and human values; and to expand the range of economic and social choice available to individual and nation. Development, therefore, will involves a transformation of the individuals and thus the society from a stand point of view to more useful and more desirable stand point. Since human beings are the primary agent of positively transforming a society, human development is central to all forms of societal progress and prosperity.

\section{The National Economic Empowerment and Development Strategy (NEEDS)}

NEEDS is homemade or Nigeria's home grown medium - term development and poverty reduction package. It focuses on the country's macroeconomic, structural, and social policies and programmes for promoting growth and reducing poverty, through a participatory process involving all segments of the society. It is distinctively a Nigeria development vision with four main support institutions pillar or strategies. These are reforming government and institutions, growing the private sector, implementing a social charter, and value re-orientation of the citizenry. The Committee of Vice-Chancellors of Nigerian Universities (CVCNU, 2004) has summarized the four main features of NEEDS in terms of their human development requirements. They are as presented below.

\subsection{Reforming Government and Institutions}

This reform agenda of Government refers of changing the ways the government systems and institutions work in this country. These include privatization and market liberalization, economic coordination and institutional reforms, redefining the role of government which is concerned with the public - private sectors partnership and the monetization 
of fringe benefits in the Federal Public service. For the success of this segment of NEEDS strategies, CVCNU (2004), note that training and retraining of existing personnel are required. That the universities be availed the opportunity to design and mount specific-purpose training/retraining programmes and play leading role in providing consulting services. This will ensure the building of needed critical mass of seasoned administrators and leaders to ensure sustainability of NEEDS. Thus human development comes top for this segment.

\subsection{Growing the Private Sector}

NEEDS envisages a private driven sector economy for employment generation and wealth creation. The growth of the economy anywhere in the world depends on the emergence, behaviour and performance a variety of entrepreneurs and innovators. These groups of people have to be nurtured to perform effectively. This will also involve education, training, development and research. This paradigm of a private sector - led economy will call for massive development of the human asset. The development of entrepreneurs and innovators to stimulate the private sector growth becomes an urgent matter. This is because the generation of high level of employment opportunities and wealth creation by the entrepreneurs and an expanded private sector will greatly reduce poverty in the society.

\subsection{Implementing a Social Charter}

The NEEDS social charter is about people. The specific issued address in the segment of the strategy include; social welfare, health, education, employment and general participation in economic and democratic processes. In all of them human development is critical. CVCNU (2004), note that Universities specifically have to play a leading role in the enlightenment of the populace, which is a key success factor. This is because combating the scourge of HIV/AIDS, malaria, tuberculosis are involved and people have to be trained in the medical schools. Also agriculturalists have to be developed and facilities must be provided to meet the challenges and people should be empowered with required inputs. The NEEDS social mobilization requires people who are trained to perform needed functions.

The social charter therefore involves human development agenda in education, health, housing, women and youth empowerment, safety net and strengthening peace and internal security. Thus human development quite distinct from the concepts of growth and development can check the spread of poverty consequently their must be access to education.

\subsection{Re-Orienting the Value System of the Populace}

Value re-orientation is about behavioral or attitudinal change. Any change involves de-freezing of old and undesirable habits and the refreezing of valued behavior. For it to take root in the minds of people and succeed, mass education, training development and enlightenment are very important. The educational institutions, of all classes have to produce men and women with the right orientation needed for the performance of various activities that are involved in the other three pillars of NEEDS. As noted earlier on societal vices and negative behavior have made nonsense of over past development plans. The emphasis on value re-orientation in this new development programmes is well placed. This must be match with strict sanctions for undesirable behavior.

\subsection{NEEDS as Socio-Economic Development Programme (SEDP)}

The success of NEEDS based on the four pillars described above will depend on massive human development of the populace. NEEDS constitutes a Socio-Economic Development Programme for Nigeria in a democratic environment. Ekpo-Ufot (1990) defines Socio-economic Development (SED), "as a process of growth and expansion into some needed and socially useful forms of individuals, natural resources and man-made resources of a given region". The accumulation of such new and socially useful forms constitutes the wealth of a region; in this view SED is a process of wealth development. The chief agents in the wealth development process are the creative individuals of the region. The process itself is churned with the techniques or technologies devised by the creative individual agents. Technologies as used here refer to all processes of employing knowledge, skills, insights and attitudes in solving societal problems.

The most salient indicators of SED as noted by Ekpo-Ufot (1990) in our view are: the creative individuals, new technologies, new products, new services and accumulated stock of added wealth. The obvious fact is that all the other items of wealth stem from the first: creative individuals. Since NEEDS as describe earlier on is a process of wealth creation and development its effective functioning and success depends on the creative individuals on which SED lays serious emphasis. Such creative individuals will be foundation for the nation's self-reliance, which, Ekp-Ufot (1990) tagged as self-sufficiency in the stock of wealth. Thus a self-reliant individual is a creative person who has used his/her creativity to device technologies to produce goods and services that meets his/her needs. A self-reliant nation is the one most of whose citizens have reached their creative potentials, and they use these to develop indigenous technologies for producing goods and services for the consumption of their fellow citizens. The process of nurturing individuals to be creative in the forms expressed above calls for massive and new patterns of education, training and 
development of the human resource.

\section{Model for Projecting Impacts of NEEDS on Human Development}

The model to be presented envisages a collaborative and interactive relationship between the educational system, the private business organizations, industrial groups, other forms of social organizations, with the government playing the role of a big brother, in the cooperative effort for massive human development. The process is expected to produce new and creatively and positively oriented breeds of managers, engineers, architects, lawyers, doctors, accountants, entrepreneurs, researchers, administrators and endless list of skilled professionals. Figure I depict the types of relationships that are expected for effective impacts on human development processes.

The most important institutions of human development as shown in Figure I are the schools and the factory. The model shows them sandwiched together by double-headed arrows. Ascending arrows in the school system shows academic career growth, whereas descending arrows underline the role of the higher institutions to provide instruction to the lower levels. In the factory column seven main factors are listed to define the structure of the manufacturing industry. Ekpo-Ufot (1990), notes that the ordering depends on the preferred order of' attack, beginning with numbers 2 and 3 food processing and motor vehicles simultaneously. The intermediate outcome depicts graduates from the twin institutions based on the process of human development. Their functions after graduation are in the areas of research and development

(R \& D). Thus scientists are expected to be dominantly engaged in basic research, applied research and exploratory development research. They must also be in touch with development activities, the craftsmen on the other extreme are with development activities in the production line. All of these individuals must acquire inquisitive mind to raise questions about their work, continually in search for new knowledge and new ways of doing things. The craftsmen will be progressing up the professional careers and will be carrying their experiences and ideas to refine as they grow higher. Ekpo-Ufot (1990) notes that the technologists, engineers, managers and other professionals based on this model have to divide their time equally between the important functions of R and D - hence these shown in capital for them.

\subsection{Requirements for the Successful Implementation of the Model}

The success of the model in having the necessary impacts on human development calls for thorough re-examination of our educational system in line with the demands of NEEDS, for human development as noted above. At the primary level pupils must be taught how to apply their skills in reading, writing, computation and sciences in solving problems of the society and have skills that can be used in providing goods and services. Thus, infants now and in the future are to be developed to be visionary conscious, to have self-awareness, risk taking confidence and initiated into intuitive sensitivity of seeing order in disorder through practice and deep listening. This called for a redevelopment of teachers that work at this level.

At the secondary level the 3-3 systems must be made functional with necessary equipment and personnel. During the first three years teacher are to build on the foundations laid at the lower level, and students are to be trained in various vocations. In the last three years the students will focus in areas where they have exhibited the best competence of contributing most to the societal development again, at this level there will be need for the development of the trainers in line with the new practical requirement.

At the tertiary level which includes colleges of education, polytechnics and the universities, a functional blend between theory and practice must be put in place. This will result in producing doctors, engineers, managers, accountants, researchers and other professionals who are creative individuals that have developed skills in solving problems of the society by producing goods and services for society corruption.

\section{Proposed Pattern of Education and Development based on NEEDS requirement for Human Development.}

It is to be noted that significant changes in performance will stem from strategic development of the human asset (Oghojafor, 1998). Consequently, we propose three broad categories of human development in response to NEEDS requirement. This will ensure that real productive and creative educated individuals come out the system of our model, to create a self-reliant nation. These are (i) the functional, (ii) behavioral and (iii) environmental processes of human development.

\subsection{Functional Development Method}

This method aims at developing functional skills that are essential for successful running and performance in the individuals chosen field of enterprises e.g. engineering, entrepreneurship, managing, accounting etc. In addition the individuals must have the following skills; planning skills, initiating skills, allocating tasks and setting standards, controlling skills, support skill, information skill, evaluation skill, development of technical, technological and professional competencies needed for productive work employment. Others are enterprise building skill and 
development of managerial capacity to run business and other productive activities successfully.

\subsection{Behavioral Development Method}

The values re-orienting aspect of NEEDS is an emphasis on changing the negative and undesirable behaviors to positive and societal valued behavior. This method will centre on inculcating and developing in people desirable attributes, attitudes, values, beliefs, norms, customs, perception, motives and needs. It is the development of human spirit, characteristics and personality. Since personality issues are involved other relevant attributes are personality traits, leadership, innovation and development in creative ideas. Serious emphasis should be placed on discipline behavior. Attitudinal change is important because the attitude of people determines their altitude in terms of goal attainment and effective performance. The functional and the behavioral human developmental methods are people change approaches that must be carried out in the process of education, training and development in formal educational institutions industries, seminar groups and so on. It calls for total reorientation of all Nigeria. It requires massive human development efforts. It is a process of developing in the individual ideals of patriotism, disciplined behavior self-awareness and values re-orientation.

\subsection{Environmental Development Methods}

This is an aspect of education which is beyond the direct influence of the individual. It has to be done to him/her by others. This means that impetus must be provided by others outside the person. Thus a family environment that encourages hard work and disciplined behavior could be a better breeding place for developing the creative individuals. Formal education with emphasis on need for achievement, self-actualization and visionary outlook could lead to a rise in the level of creative individuals. The government support system for the massive education required by NEEDS in human development is important. Availability of financial assistance and conducive urban and rural environments could produce or stimulate innovative individuals who will be real torchbearers in the implementation of NEEDS for self-reliance and sustainability.

\section{Projecting the impacts of NEEDS on Human Development}

We here attempt the gaze into future with respect to human development based on our perception of NEEDS as a socio-economic development programme which is a people-centered development strategy. In our brief discussion on NEEDS it was noted that successful implementation of each of its four thrusts requires tremendous human resources development to cope with several challenges and exploit wide ranging of opportunities. As noted in several sections of this paper we require new approaches and new values system in our educational, training and development institutions which should also be people-centered and result oriented rather than producing people who have only paper qualifications without being able to make meaningful contributions in the socio-economic development programme of the country. The starting point is massive publicity on NEEDS as a concept and the expected roles of individuals, organizations, educational institutions and communities in the process of human development to meet the envisaged demands for improved human performance NEEDS must therefore take root in the minds of people.

The model of the discourse (Figure 1) shows expected patterns of human resource development in terms of interactions between educational institutions private organization and the government. Proper utilization of the model for human development is expect to turn out large number of people in various professional areas. These are the creative individuals in forms of innovators, engineers, entrepreneurs, accountants, lawyers and so on. These are the set of people who will successfully implement the policies and programmes of NEEDS. Oghojafor (2000) notes that the best formulated strategies are of no benefit if they cannot be implemented successfully. Successful implementation of NEEDS calls for intensive and extensive human development programmes in formal and informal educational institutions. It calls for a number of adjustments in the present educational system. These are discussed below:

\subsection{Schools Curricula Contents Redesign}

Schools curricula should include the plans, intentions, hopes, fears, dreams and other such agents as teachers, students, curricula developers and policy makers (Imade, 1983). In the case of NEEDS requirements practice oriented curricula, based on demands of its thrust are need, we should not rigidly tie ourselves to imported curricula models, our model should be given the supports for practical implementation. Therefore redesigning appropriate curricula for the various levels of the educational system and their effective implementation will tremendously aid the process of implementing NEEDS programmes.

\subsection{Effective Management of the Human Development System}

Human development in formal and informal educational institution and other spheres of skills acquisition must be managed effectively. This calls for further development of the managers and administrators in our educational system for them to be realigned properly with the human development demands of NEEDS. The projected impacts of NEEDS in summary, from our perspective are to have a self-reliant, great and dynamic economy. It becomes necessary, 
therefore, to develop multidimensional skills in people that pass through our educational system. Ogundele (2005a) presents three broad categories of skills development;

(i) Management development perspective skills: This range from time management, self-development, managing change, decision making, human resource environment, project management, process redesign, total quality management, organizational development, corporate excellence and people skills.

(ii) Interpersonal skills: They include, leadership, subordinate development, delegation, counseling, information technology, re-engineering values, managing information, employee empowerment, conflict management, negotiation and communication skills.

(iii) Cross -sectional skills: These are innovation or creativeness, planning organizing and human relations skills. Processes of acquiring these skills demand serious planning and effective implementation of human development programmes. The implementation strategy for the skill development must be dynamic and reflects societies own values and in line with operating laws (Ogundele, 2005b).

\section{Government Approach to Reforming Government and Institution}

This is another kind of adjustment that is very important. The objectives are restoration of good governance, promotion of sustainable growth and acceleration of the pace of poverty eradication in Nigeria. Samaila (2005) notes that public service sector's reforms are being implemented within four domains:

(i) Financial and economic reforms through accelerated privatization of government of owned companies and agencies and the liberalization of the economic and legal atmosphere. (ii) public service reforms which involve the refocusing and repositioning of the public service for effective service. (iii) governance and institution strengthening which involves efforts at reducing the cost of governance and also decentralization in terms of fiscal federalism, local government community empowerment, re-equipping the law enforcement agencies for crime prevention and control, and maintenance of law and order. (iv) transparency, accountability and anti-corruption efforts. This is through the activities of the Independence Corrupt Practice and other related offences Commission (ICPC) and the Economic and Financial Crime Commission (EFCC).The truth is that NEEDS requires a reformed financial and economic system, public service, government and institutions and a moralized environment for its success. Therefore, these reforms call for changes in perceptions, attitudes, practices and behavior, for human development in the affected sectors.

The NEEDS document produced by the National Planning Commission (2005) made number of claims that it is the people's plan for prosperity, It coordinates action at the federal and state levels, and it is a feasible plan. But at the time when NEEDS Phase I terminated in 2007, there was little to show in terms of targeted achievement. For example, the document claimed that, providing more and more reliable power could triple the volume of production in Nigerian Industries by June, 2007, but the power is still as bad as ever. Also, the document states that future prosperity depends on producing children who are well prepared to take their place in tomorrow's global society, but the educational sector is as chaotic as it was before the start of NEEDS, hence the need for necessary adjustment. NEEDS phase II commenced in June, 2007, with the expectation of spearheading Nigeria's industrialization. Akintunde and Ojiabor(2006) reported that the implementation of NEEDS Phase II would build on the achievements of NEEDS Phase I, which started in 2004. Under NEEDS Phase II, it was stated that there would be a focus on employment generation and aggressive public infrastructural development. As at 2010 the objectives of NEEDS phase II which among others is to establish Nigeria as one of the largest industrialized nations has not been achieved.

\section{Recommendations}

Flowing from the various sections of this paper the following recommendations are put forward for human development to make NEEDS a big success in the very near future.

i. There should be emphasis on self-reliance as a practice in all our educational levels

ii. There should be practical and not paper emphasis on pure science and science related specialization areas in our secondary and tertiary educational institutions (Ogundele, 2005c).

iii. The government should spearhead the suggested the collaborative effort between the three parties i.e. the government, educational system and private organization.

iv. NEEDS planners and operators should set specific targets and time framework of human development for Nigeria to be self-sufficient in the areas of basic needs.

v. Government to give more support to indigenous organizations that are in the forefront of research and development.

iv. Creation of an enabling environment by the government which will promote human development and consequently the development of equipment and products (Ogundele, 2005c). 


\section{Conclusion}

NEEDS is a response to Nigeria's past failures. It recognizes the inadequacies of past models of development. It is based on the power of ideas. Soludo (2004), notes that $60 \%$ of the success of any venture can be explained by the power of ideas behind it. To be really successful in a big way, have big idea. Nothing becomes big without a big idea behind it. When the idea is right and powerful and you have people who are dedicated to implement it and there are appropriate strategies, there will be resounding success. Every great country that had development had great idea behind it. NEEDS is Nigeria's home made idea for human and economic development. It recognizes the views of critical mass of Nigerians who value excellence, integrity, hard work, good performance, dedication and commitment to duty to the Nation, accountability and dedication to a course in which one believes. NEEDS' success requires people who believe in the project - "NIGERIA". If you do not believe in a project there will be no commitment. Without patriotism Nigeria can never move forward. Soludo (2004), notes that NEEDS is a war of a thousand battles. We are into a war of development, we want to create jobs in this country and other countries also want to create jobs

in their places. We therefore have to develop well trained personnel for this war. The work is plenty but labor is few, so human development comes top. NEEDS's success will depend on people who believe in the concept who are committed to it and patriotic. NEEDS is about re-orienting of values. NEEDS talks about creating wealth and it also, talk about creating values. We must throw away the value system of something for nothing. Nigeria cannot develop with a culture of moving to stupendous wealth from nothing by sheer connection. No other people will develop Nigeria but Nigerians; this is the message of NEEDS. That is why NEEDS is anchored on human development in many dimensions.

Therefore, we require an evangelistic human development of indigenous entrepreneurs and various professionals equipped with all needed supports for effective performance. The practice of valued behaviors must be encouraged and enforced. Equally, violators of social and economic ethics should no longer be spared. These will be necessary foundations for reaping the full impacts of human development for the success of NEEDS.

\section{References}

Akintoye, E. K. and Awosika, G. A. (2000). Development Theories and Administration: A Nigerian Perspectives, Lagos: Alsum International Ltd.

Anyanwu, J. C., Oyefusi, A., Aoikhenan, H., and Dimowo, F.A. (1997). The Structure of Nigerian Economy 1960 1997, Onitsha: Joanele Education Publishers Ltd.

Akintunde,O and Ojiabor,O. (2006). NEEDS II to spearhead Nigeria's Industrialization. The Punch. Friday. October 13, Vol.17, No.19710, p.26.

Baech P. S. (1975). Personnel Management of People at Work, New York: MacMillanPublishing Co.

Committee of Vice-Chancellors of Nigerian Universities. (2004). The roles of Nigerian Universities System in the implementation of the National Economic Empowerment and Development Strategy, (NEEDS). National Universities Commission, Abuja, April.

Ekpo-Ufot, A. (1990). Research and development management: A strategy for Developing Indigenous technology and Self-reliance Monthly Technical Seminar Series, Federal Ministry of Science and Technology, 9, Kofo Abayomi Street Victorial Island, Lagos.

Fadeyi, A. O. (2004). Gender equality in Nigeria: Challenge to sustainable development, First International Conference of Faculty of Social Sciences, Lagos State University, Ojo, November $30^{\text {th }}-2^{\text {nd }}$ December.

Imade, V. O. (1983). Curriculum Development for Accelerated Modernization, Journal of Management Education and Training, vol. 1, No. 1, $101-123$.

National Planning Commision. (2005). National Economic Empowerment and Development Strategy,(NEEDS). Abuja. Central Bank of Nigeria.

Oghojafor, B. E. A. (1998). Strategic Management and Business Policy, Lagos: Malthouse Press Ltd.

Oghojafor, B.E.A. (2000). Strategic Management: Questions and answers with notes: Lagos: Malthouse Press Ltd.

Ogundele, O. J. K. and Opeifa, A. Z. (2004). Business regulation and control, in Ogundele O.J.K. (Ed). Introduction to Business Organisation: A book of Readings, 237 - 261, Lagos: Molofin Nominees.

Ogundele O. J. K. (2005a). Entrepreneurship Development for great and dynamic economy, Conference paper, Association for encouragin qualitative Education in Nigeria, Ambrose Alii University, Ekpoma $9^{\text {th }}-13^{\text {th }}$ May.

Ogundele O.J. K. (2005b) Installing ethical vision and mission in the environment in the $21^{\text {st }}$ Century in Nigeria, 
Conference paper $7^{\text {th }}$ Annual Conference, National Association for Advancement of Knowledge NAFAK, FCT College of Education, Zuba-Abuja, $7^{\text {th }}-11^{\text {th }}$ March.

Ogundele O.J.K. (2005c). Partnership for developing indigenous technology for economic self-reliance, Proceedings of the International Conference in Engineering 2005, 528 - 537, Faculty of Engineering, Universities of Lagos, Nigeria, 23 - 26 May.

Olayide S. O. (1976). Economic Survey of Nigeria 1960 - 1975, Ibadan: Aromolarun Publishing Company Ltd. Samaila, A. (2005). Understanding OBJ's reforms Sunday Sun, vol. 2, No. 114, 38, $2^{\text {nd }}$ May.

Soludo C. (2004). Address of the Governor of the Central Bank of Nigeria (CBN) at the National Conference on NEEDS, NEEDS Research Unit, Department of Economics University of Lagos, Akoka, $23^{\text {rd }}-24^{\text {th }}$ September.

Torado, M. P. and Smith, S. C. (2003). Economic development $4^{\text {th }}$ ed., Delhi: Pearson Education.

Yesufu, T. M. (1996). The Nigerian Economy: Growth without Development, The Benin Social Scheme Series for Africa, Benin: University of Benin.

\section{The School}

The Factory
Intermediate Outcome

Ultimate Outcome

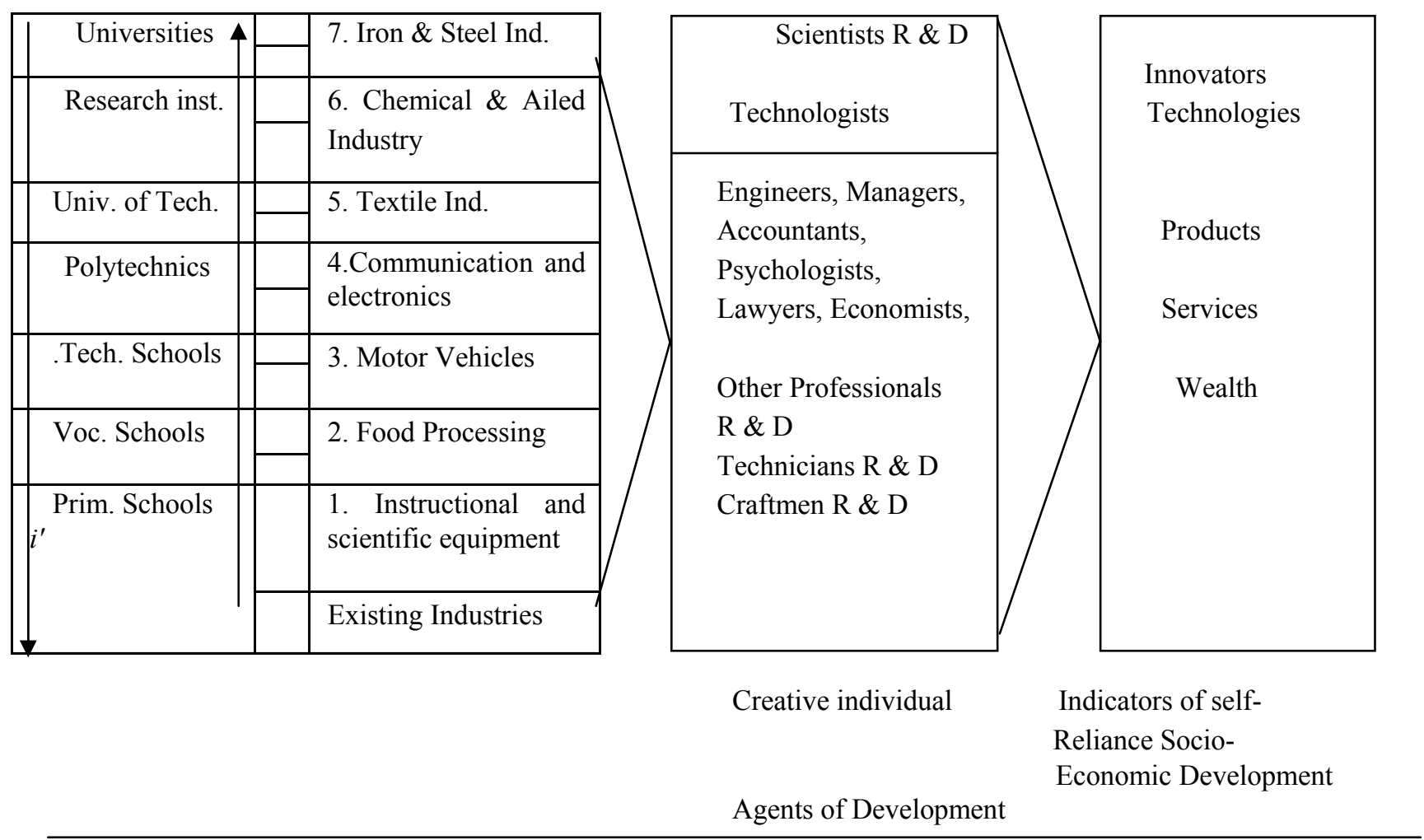

Source: Adapted from Ekpo-Ufot, A. (1990) General Model of Self-reliance Socio-Economic Development

Figure 1. Model of Collaborative and Interactive Human Development Processes 